\title{
Implementasi Kebijakan Penanggulangan Bencana Banjir di Masyarakat Kota Medan Tahun 2020
}

\author{
M Edwin Fransiari, Sony Priajaya Warouw, Netty Etalia Brahmana \\ Program Studi Magister Kesehatan Masyarakat Direktorat Pascasarjana Universitas Sari Mutiara \\ Indonesia, Jl. Kapten Muslim No. 79 Medan 20123, Indonesia \\ Email : Edwinfransiari@gmail.com
}

\begin{abstract}
Abstrak
Latar belakang: Salah satu fenomena alam yang menimbulkan kerugian besar dan dapat mengancam beberapa wilayah di Indonesia adalah bencana banjir. Penelitian ini bertujuan untuk mengevaluasi implementasi kebijakan bencana banjir di Kota Medan serta untuk mengetahui faktor-faktor pendorong dan penghambat penanggulangan bencana banjir di Medan. Metode: Penelitian penelitian ini menggunakan desain kuantitatif dengan penerapan metode penelitian deskriptif analitik. Besar sampel adalah 106 orang dengan tehnik pengambilan sampel acak sederhana. Analisis data menggunakan univariat, bivariat dan multivariat dengan menggunakan korelasi spearmen dan uji chi square. Hasil: Terdapat hubungan antara keberhasilan implementasi kebijakan dengan faktor komunikasi dengan nilai $p=0,016$, sumber daya dengan nilai $p=0,0001$, disposisi dengan nilai $p=0,0001$, struktur birokrasi dengan nilai $p=0,001$. dan berdasarkan hasil analisis multivariat, variabel yang paling berpengaruh dengan keberhasilan implementasi kebijakan adalah struktur birokrasi dengan nilai $(\mathrm{OR}=26,787 ; 95 \% \mathrm{Cl}: 5,546$ $129,365)$, diikuti faktor sumber daya dengan nilai $(\mathrm{OR}=22,484 ; 95 \% \mathrm{Cl}: 4,653-108,36)$, lalu faktor komunikasi dengan nilai $(\mathrm{OR}=11,274 ; 95 \% \mathrm{Cl}: 5,546-129,362,516-50,5245)$ dan faktor disposisi dengan nilai $(\mathrm{OR}=8,191 ; 95 \% \mathrm{Cl} 1,936-34,165)$. Simpulan: faktor yang paling dominan dalam mempengaruhi keberhasilan dari implementasi kebijakan penanggulangan banjir di kota Medan adalah stuktur birokrasi.
\end{abstract}

Kata Kunci : Evaluasi, Implementasi Kebijakan, Faktor Penghambat.

\begin{abstract}
Background: One of the natural phenomena that causes huge losses and can threaten several regions in Indonesia is flood disaster. This study aims to evaluate the implementation of flood disaster policies in Medan City and to determine the driving and inhibiting factors for flood disaster management in Medan. Methods: This type of research uses a quantitative design with the application of analytical descriptive research methods. The sample size was 106 people with simple random sampling techniques. Data analysis used univariate, bivariate and multivariate using spearmen correlation and chi square test. Results: There was a relationship between the successful implementation of the policy and the communication factor with a value of $p=0.016$, resources with a value of $p=0.0001$, disposition with a value of $p=0.0001$, bureaucratic structure with a value of $p=0.001$. and based on the results of multivariate analysis, the variable that most influences the success of policy implementation is the bureaucratic structure with a value $(\mathrm{OR}=26,787 ; 95 \% \mathrm{Cl}: 5,546-129,365)$, followed by resource factors with a value $(\mathrm{OR}=$ $22,484 ; 95 \% \mathrm{Cl}: 4,653-108,36)$, then the communication factor with the value (OR $=11,274 ; 95 \%$ $\mathrm{Cl}: 5,546-129,362,516-50,5245)$ and the disposition factor with the value $(\mathrm{OR}=8,191 ; 95 \% \mathrm{Cl}$ 1,936-34,165).. Conclusion: The most dominant factor affecting the successful implementation of flood prevention policies in Medan City is the bureaucratic structure.
\end{abstract}

Keywords: Evaluation, Policy Implementation, Inhibiting Factors.

http://ejournal.urindo.ac.id/index.php/kesehatan

Article History :

Sumbitted 19 Juni 2021 Accepted 30 Desember 2021, Published 31 Desember 2021 


\section{Pendahuluan}

Indonesia merupakan negara yang memiliki berbagai macam sumber daya alam serta keanekaragaman hayati yang besar di dunia ini. Selain memiliki sumber daya alam tersebut ternyata Indonesia juga memiliki potensi bencana yang bersumber dari alam, baik bencana alam geologis maupun bencana alam yang diakibatkan ulah manusia. Kepulauan Indonesia berada pada pertemuan tiga lempeng tektonik raksasa yaitu eruasia, india australia dan Pasifik dan terletak diantara Benua Asia dan Australia dan Samudera Hindia dan Pasifik, serta terdiri dari \pm 17.000 pulau yang sebagian besar berhadapan dengan laut lepas dengan garis pantai lebih dari $81.000 \mathrm{~km}$. Posisi geografis tersebut, menyebabkan Indonesia rentan terhadap berbagai macam bencana (BNPB RI, 2017).

Salah satu fenomena alam yang menimbulkan kerugian besar yang selalu mengancam beberapa wilayah di Indonesia adalah bencana banjir. Banjir merupakan suatu fenomena alam biasa, namun akan menjadi suatu yang sangat merugikan jika mengancam keberadaan hidup manusia. Berdasarkan nilai kerugian dan frekuensi kejadian bencana banjir terlihat adanya peningkatan yang cukup berarti. Kejadian bencana banjir sangat 76 dipengaruhi oleh faktor alam berupa curah hujan yang diatas normal dan adanya pasang naik air laut.
Disamping itu faktor ulah manusia berperan penting dalam terjadinya bencana banjir (Andi, 2017).

Manajemen bencana banjir di Indonesia belum diimplementasikan secara merata seperti yang diharapkan oleh pemerintah. BNPB mencatat pada tahun 2017 terdapat 979 kejadian banjir di seluruh Indonesia dengan rincian korban sebanyak 180 orang tewas, 106 jiwa luka-luka, 2.518.579 jiwa mengungsi dan menderita, dan 16 ribu lebih rumah rusak akibat banjir. Ilmuwan lingkungan meyakini bahwa peningkatan populasi ditambah dengan efek perubahan iklim yang ekstrim menjadi penyebab bencana banjir ini Meskipun banyak pekerjaan yang telah dilakukan oleh pemerintah Indonesia untuk mengelola masalah banjir seperti anggaran masalah alokasi, masalah kesadaran, dan kebutuhan akan para ahli yang memadai menjadi tantangan dalam mencapai risiko banjir yang efisien manajemen (BNPB 2017).

Provinsi Sumatera Utara memiliki tingkat kerentanan terhadap bencana alam yang cukup tinggi khususnya bencana banjir dan longsor. Luas areal di Provinsi Sumatera Utara yang mengalami bencana banjir adalah seluas $12.805 \mathrm{~km} 2 \quad(17,86 \%)$. Wilayah yang mengalami tingkat risiko sangat tinggi terhadap banjir meliputi 12 Kabupaten/Kota di wilayah Provinsi Sumatera Utara antara lain : Kabupaten Langkat, Kabupaten Deli Serdang, Kota 
Medan, Kabupaten Serdang Bedagai, Kota Tebing Tinggi, Kota Tanjung Balai, Kabupaten Asahan, Kabupaten Batubara, Kabupaten Mandailing Natal Kabupaten Tapanuli Selatan, Kabupaten Tapanuli Tengah, dan Kabupaten Nias. Pada tahun 2017 di provinsi Sumatera Utara terdapat jumlah kejadian banjir sebanyak 45 kejadian dengan jumlah korban sebanyak 14 orang meninggal, 2 orang luka-luka dan 174.740 orang mengungsi, sedangkan dari jumlah kerusakan sarana dan prasarana sebanyak 214 rumah rusak berat, 287 rumah rusak ringan dan 35.128 rumah terendam banjir (BNPB 2017).

Kota Medan sebagai salah satu kota metropolitan di Indonesia tidak terlepas dari masalah banjir. Salah satu wilayah yang berpotensi dilanda banjir di Kota Medan yaitu DAS Babura, bagian dari DAS Deli di bagian hulu yang mempunyai topografi berupa perbukitan dan semakin ke hilir bertopografi dataran.Daerah Aliran Sungai adalah suatu daerah yang dibatasi oleh pemisah topografi yang berfungsi untuk menerima, mengumpulkan air hujan, sedimen, dan unsur hara serta mengalirkannya melalui anak-anak sungai dan keluar pada satu daerah. Daerah yang tergenang banjir akibat meluapnya Sungai Babura terdiri dari 13 kelurahan, yaitu Kelurahan Darat, Merdeka, Padang Bulan, Petisah Hulu, Titi Rantai, Anggrung, Polonia, Madras Hulu, Suka Damai, Beringin, Kwala
Bekala, Pangkalan Masyhur, dan Gedung Johor. Luas genangan yang paling besar terdapat di kelurahan Kwala Bekala dengan luas genangan sebesar $4.171 \mathrm{Km}^{2}$ dan di kelurahan Pangkalan Mashyur dengan luas genangan sebesar $4.493 \mathrm{Km}^{2}$. Estimasi biaya kerusakan rumah akibat banjir di DAS Babura di kelurahan Kwala Bekala ialah sebesar Rp 5.886.226.643 dan di kelurahan Pangkalan Mashyur ialah sebesar Rp 5.575.224.667 (Meidina, 2017).

Hasil penelitian Christo Immanuel (2015) tentang Implementasi Kebijakan Penanggulangan Bencana di Kabupaten Minahasa Tenggara menunjukan bahwa tingkat keberhasilan implementasi penanggulangan bencana di Kabupaten Minahasa Tenggara berada pada kategori "sedang" atau cukup berhasil. Hal ini menunjukkan bahwa implementasi kebijakan penaggulangan bencana di daerah ini belum optimal. Hal ini terkendala oleh belum memadainya ketersediaan sumber daya, terutama jumlah dan mutu sumber daya manusia pelaksana kebijakan penanggulangan bencana itu sendiri.

$$
\text { Hasil penelitian Adinda (2014), }
$$
mengenai evaluasi implementasi kebijakan dalam penanggulangan bencana banjir, tidak ada pertemuan yang secara khusus mengatur tentang penanggulangan bencana di Kota Bekasi. Koordinasi yang dilakukan khusus untuk penanggulangan bencana 
diadakan hanya pada saat terjadinya Kejadian Luar Biasa (KLB).

Hasil penelitian Feny Irfany (2019) Implementasi Kebijakan Mitigasi Bencana Banjir oleh BPBD Desa Dayeuhkolot Kabupaten Bandung belum berjalan dengan maksimal, masih terdapat permasalahan dan kendala yang dihadapi dalam pelaksanaan tersebut. Hal ini ditandai dengan Pencegahan Bencana Banjir, Penanganan Darurat Bencana Banjir, Rehabilitasi dan Rekontruksi bencana banjir masih banyak ditemukan permasalahan.

\section{Metode}

Penelitian ini menggunakan desain kuantitatif dengan penerapan metode penelitian deskriptif analitik, hal ini berdasarkan atas tujuan dari penelitian ini yaitu ingin mengetahui keberhasilan implementasi kebijakan penanggulangan bencana banjir di kota Medan dan faktorfaktor yang menentukan terhadap keberhasilan implementasi kebijakan penanggulangan bencana dan besarnya kontribusi faktor-faktor tersebut terhadap keberhasilan implementasi kebijakan penanggulangan bencana banjir di Kota Medan.

Penelitian ini dilaksanakan Kecamatan Medan Johor, Keluahan Kwala Bekala dan Pangkalan Masyhur. Penelitian ini dilaksanakan selama 9 bulan yaitu terhitung mulai bulan Februari - Oktober 2020. Populasi dalam penelitian ini adalah seluruh Kepala Keluarga yang berada di Lingkungan III kelurahan Kwala Bekala dan lingkungan VIII Kelurahan Pangkalan Mashyur, Kecamatan Medan Johor, yang berjumlah 432 orang, Teknik pengambilan sampel dalam penelitian ini menggunakan teknik sampel acak sederhana (Simple Random Sampling), Untuk menentukan jumlah sampel yang diambil, peneliti menggunakan rumus dari Frank Linch (1974:18).

\section{Hasil dan Pembahasan}

Tabel 1. Persentase karekteristik responden di Kelurahan Kwala Bekala dan Pangkalan Masyhur

\begin{tabular}{ccc}
\hline Karakteristik & Jumlah & Persentase \\
\hline Jenis Kelamin & & \\
\hline Laki - laki & 60 & $57 \%$ \\
\hline Perempuan & 46 & $43 \%$ \\
\hline
\end{tabular}

Tabel 2. Kategori keberhasilan implementasi dalam penanggulangan bencana di Kelurahan Kwala Bekala dan Pangkalan Masyhur

\begin{tabular}{ccc}
\hline Kategori & Frekuensi & Persentase \\
\hline Baik & 74 & $69,8 \%$ \\
\hline Tidak baik & 32 & $30,2 \%$ \\
\hline Total & 106 & $100 \%$ \\
\hline
\end{tabular}

Tabel 3. Kategori keberhasilan komunikasi dalam penanggulangan bencana di 
Kelurahan Kwala Bekala dan Pangkalan Masyhur

\begin{tabular}{ccc}
\hline Kategori & Frekuensi & Persentase \\
\hline Berhasil & 66 & $62,3 \%$ \\
\hline $\begin{array}{c}\text { Tidak } \\
\text { berhasil }\end{array}$ & 40 & $37,7 \%$ \\
\hline Total & 106 & $100 \%$
\end{tabular}

Tabel 4. Kategori keberhasilan sumber daya dalam penanggulangan bencana di Kelurahan Kwala Bekala dan Pangkalan Masyhur

\begin{tabular}{ccc}
\hline Kategori & Frekuensi & Persentase \\
\hline Cukup & 66 & $62,3 \%$ \\
\hline Tidak cukup & 40 & $37,7 \%$ \\
\hline Total & 106 & $100 \%$ \\
\hline
\end{tabular}

Tabel 5. Kategori keberhasilan disposisi dalam penanggulangan bencana di Kelurahan Kwala Bekala dan Pangkalan Masyhur

\begin{tabular}{ccc}
\hline Kategori & Frekuensi & Persentase \\
\hline Baik & 66 & $62,3 \%$ \\
\hline Tidak baik & 40 & $37,7 \%$ \\
\hline Total & 106 & $100 \%$
\end{tabular}

Tabel 6. Kategori keberhasilan struktur birokrasi dalam penanggulangan bencana di Kelurahan Kwala Bekala dan Pangkalan Masyhur

\begin{tabular}{ccc}
\hline Kategori & Frekuensi & Persentase \\
\hline Baik & 63 & $59,4 \%$ \\
\hline
\end{tabular}

\begin{tabular}{ccc}
\hline Tidak baik & 43 & $40,6 \%$ \\
\hline Total & 106 & $100 \%$ \\
\hline
\end{tabular}

Diperoleh bahwa sebanyak $79 \%$ responden dengan tingkat keberhasilan implementasi yang baik dan komunikasi yang berhasil. Hasil analisis statistik menunjukkan ada hubungan yang bermakna antara faktor komunikasi dengan tingkat keberhasilan implementasi kebijakan bencana banjir (Tabel 7).

Tabel 7. Hubungan Faktor Komunikasi dengan Keberhasilan Implementasi

\begin{tabular}{|c|c|c|c|c|c|c|}
\hline \multirow{3}{*}{ Komunikasi } & \multicolumn{4}{|c|}{$\begin{array}{c}\text { Kategori } \\
\text { keberhasilan } \\
\text { implementasi }\end{array}$} & \multirow{3}{*}{ Total } & \multirow{3}{*}{$\begin{array}{c}\text { Hasil } \\
\text { Analisis } \\
\text { Statistik } \\
\quad(p- \\
\text { value) }\end{array}$} \\
\hline & \multicolumn{2}{|c|}{$\begin{array}{l}\text { Tidak } \\
\text { Baik }\end{array}$} & \multicolumn{2}{|c|}{ Baik } & & \\
\hline & $\mathrm{N}$ & $\%$ & $\mathrm{~N}$ & $\%$ & & \\
\hline $\begin{array}{c}\text { Tidak } \\
\text { Berhasil }\end{array}$ & 18 & 45 & 22 & 55 & 40 & $p=0,016$ \\
\hline Berhasil & 14 & 21 & 52 & 79 & 66 & \\
\hline
\end{tabular}

Hubungan antara variabel komunikasi terhadap keberhasilan implementasi penanggulangan bencana dalam penelitian ini menunjukkan hasil yang positif dan signifikan dengan nilai koefisien determinasi $\left(r^{2}\right)$ sebesar 0,251 atau $25 \%$.

Berdasarkan Tabel 8 diperoleh bahwa sebanyak $84 \%$ responden dengan tingkat keberhasilan implementasi yang baik dan sumber daya yang cukup. Hasil analisis statistik menunjukkan ada hubungan yang bermakna antara faktor sumber daya 
dengan tingkat keberhasilan implementasi kebijakan bencana banjir $(p=0,0001)$.

Tabel 8. Hubungan Faktor Sumber Daya dengan Keberhasilan Implementasi

\begin{tabular}{|c|c|c|c|c|c|c|}
\hline \multirow{3}{*}{$\begin{array}{l}\text { Sumbe } \\
\text { r Daya }\end{array}$} & \multicolumn{4}{|c|}{$\begin{array}{c}\text { Kategori } \\
\text { keberhasilan } \\
\text { implementasi }\end{array}$} & \multirow{3}{*}{$\begin{array}{c}\text { Tota } \\
1\end{array}$} & \multirow{3}{*}{$\begin{array}{c}\text { Hasil } \\
\text { Analisis } \\
\text { Statistik } \\
\text { ( } p- \\
\text { value) }\end{array}$} \\
\hline & \multicolumn{2}{|c|}{$\begin{array}{c}\text { Tidak } \\
\text { Baik }\end{array}$} & \multicolumn{2}{|c|}{ Baik } & & \\
\hline & $\mathrm{N}$ & $\%$ & $\mathrm{~N}$ & $\%$ & & \\
\hline Tidak & 2 & 5 & 2 & 4 & 42 & \\
\hline Cukup & 2 & 2 & 0 & 8 & & $p=0,000$ \\
\hline \multirow[t]{2}{*}{ Cukup } & 1 & 1 & 5 & 8 & 64 & 1 \\
\hline & 0 & 6 & 4 & 4 & & \\
\hline
\end{tabular}

Hubungan antara variabel sumber daya terhadap keberhasilan implementasi penanggulangan bencana dalam penelitian ini menunjukkan hasil yang positif dan signifikan dengan nilai koefisien determinasi $\left(r^{2}\right)$ sebesar 0,392 atau 39\%.

Berdasarkan Tabel 9. Diperoleh bahwa sebanyak $82 \%$ responden dengan tingkat keberhasilan implementasi yang baik dan disposisi yang baik. Hasil analisis statistik menunjukkan ada hubungan yang bermakna antara faktor disposisi dengan tingkat keberhasilan implementasi kebijakan bencana banjir $(p=0,0001)$

Tabel 9. Hubungan Faktor Disposisi dengan Keberhasilan Implementasi

\begin{tabular}{|c|c|c|c|c|}
\hline \multirow[t]{2}{*}{$\begin{array}{c}\text { Disposis } \\
\mathrm{i}\end{array}$} & $\begin{array}{r}\text { Ka } \\
\text { kebe } \\
\text { imple }\end{array}$ & $\begin{array}{l}\text { bri } \\
\text { silan } \\
\text { ntasi }\end{array}$ & \multirow[t]{2}{*}{ Total } & \multirow{2}{*}{$\begin{array}{c}\text { Hasil } \\
\text { Analisi } \\
\text { s } \\
\text { Statisti }\end{array}$} \\
\hline & Tidak & Baik & & \\
\hline
\end{tabular}

\begin{tabular}{ccccccc}
\hline & \multicolumn{3}{c}{ Baik } & & & $\mathrm{k}(\mathrm{p}-$ \\
& $\mathrm{N}$ & $\%$ & $\mathrm{~N}$ & $\%$ & & value) \\
\hline Tidak & 2 & 5 & 2 & 5 & 40 & \\
Baik & 0 & 0 & 0 & 0 & & $\mathrm{p}=0,00$ \\
\hline Baik & 1 & 1 & 5 & 8 & 66 & 1 \\
& 2 & 8 & 4 & 2 & & \\
\hline
\end{tabular}

Hubungan antara variabel disposisi terhadap keberhasilan implementasi penanggulangan bencana dalam penelitian ini menunjukkan hasil yang positif dan signifikan dengan nilai koefisien determinasi $\left(r^{2}\right)$ sebesar 0,336 atau 33\%.

Berdasarkan Tabel 10 diperoleh bahwa sebanyak $87 \%$ responden dengan tingkat keberhasilan implementasi yang baik dan struktur birokrasi yang baik. Hasil analisis statistik menunjukkan ada hubungan yang bermakna antara struktur birokrasi dengan tingkat keberhasilan implementasi kebijakan bencana banjir $(p=0,001)$ (Tabel 14).

Tabel 10. Hubungan Faktor Struktur Birokrasi dengan Keberhasilan Implementasi

\begin{tabular}{|c|c|c|c|c|c|c|}
\hline \multirow{3}{*}{$\begin{array}{l}\text { Struktur } \\
\text { Birokras } \\
\quad \mathrm{i}\end{array}$} & \multicolumn{4}{|c|}{$\begin{array}{c}\text { Kategori } \\
\text { keberhasilan } \\
\text { implementasi }\end{array}$} & \multirow{3}{*}{$\begin{array}{c}\text { Tota } \\
\text { । }\end{array}$} & \multirow{3}{*}{$\begin{array}{c}\text { Hasil } \\
\text { Analisis } \\
\text { Statisti } \\
\mathrm{k}(\mathrm{p}- \\
\text { value) }\end{array}$} \\
\hline & \multicolumn{2}{|c|}{$\begin{array}{l}\text { Tidak } \\
\text { Baik }\end{array}$} & \multicolumn{2}{|c|}{ Baik } & & \\
\hline & $\mathrm{N}$ & $\%$ & $\mathrm{~N}$ & $\%$ & & \\
\hline Tidak & 2 & 5 & 1 & 4 & 43 & \\
\hline Baik & 4 & 6 & 9 & 4 & & $p=0,00$ \\
\hline \multirow[t]{2}{*}{ Baik } & 8 & 1 & 5 & 8 & 63 & 1 \\
\hline & & 3 & 5 & 7 & & \\
\hline
\end{tabular}

Hubungan antara variabel struktur birokrasi terhadap keberhasilan implementasi penanggulangan bencana dalam penelitian ini menunjukkan hasil yang 
positif dan signifikan dengan nilai koefisien determinasi $\left(r^{2}\right)$ sebesar 0,461 atau $46 \%$.

Hasil analisis bivariat menunjukkan semua variabel independen masuk ke dalam analisis multivariat karena semua nilai $p<0,25$ sebagai syarat untuk dimasukkan ke dalam analisis terebut.

Nilai odd ratio untuk variabel komunikasi kategori baik terhadap keberhasilan implementasi kebijakan penanggulangan banjir adalah sebesar 11,274 dengan Confidence Interval (CI) 95\% (2,516 $50,254)$, artinya responden dengan komunikasi baik 11,274 kali lebih menunjukkan keberhasilan implementasi yang baik.

Kemudian nilai odd ratio untuk variabel sumber daya kategori cukup terhadap keberhasilan implementasi kebijakan penanggulangan banjir adalah sebesar 22,484 dengan Confidence Interval (Cl) 95\% $(4,563$ - 108,631), artinya responden dengan sumber daya cukup 22,484 kali lebih menunjukkan keberhasilan implementasi yang baik.

Kemudian nilai odd ratio untuk variabel disposisi kategori baikterhadap keberhasilan implementasi kebijakan penanggulangan banjir adalah sebesar 8,133 dengan Confidence Interval (CI) 95\% (1,936 $34,165)$, artinya responden dengan sumber disposisi baik 1,936 kali lebih menunjukkan keberhasilan implementasi yang baik.
Kemudian nilai odd ratio untuk variabel struktur birokrasi kategori cukup terhadap keberhasilan implementasi kebijakan penanggulangan banjir adalah sebesar 26,787 dengan Confidence Interval (CI) 95\% $(5,546$ - 129,365), artinya responden dengan struktur birokrasi baik 26,787 kali lebih menunjukkan keberhasilan implementasi yang baik.

Dari keempat variabel yang diuji, variabel yang paling signifikan memengaruhi tingkat keberhasilan implementasi kebijakan penanggulangan banjir adalah struktur birokrasi $(p=0,001)$.

Tabel 11. Analisis Variabel yang Behubungan Terhadap Tingkat keberhasilan implementasi kebijakan penanggulangan banjir.

\begin{tabular}{|c|c|c|c|c|c|c|}
\hline \multirow[b]{2}{*}{$\begin{array}{c}\text { Variab } \\
\text { el }\end{array}$} & \multirow[b]{2}{*}{ B } & \multirow[b]{2}{*}{ Wald } & \multirow[b]{2}{*}{$p$} & \multirow[b]{2}{*}{$\begin{array}{l}\mathrm{O} \\
\mathrm{R}\end{array}$} & \multicolumn{2}{|c|}{$\mathrm{Cl} 95 \%$} \\
\hline & & & & & $\begin{array}{l}\text { Lo } \\
\text { we } \\
\text { r }\end{array}$ & $\begin{array}{l}\text { Up } \\
\text { pe } \\
\text { r }\end{array}$ \\
\hline $\begin{array}{c}\text { Komun } \\
\text { ikasi }\end{array}$ & & & & & & \\
\hline Berhasi & 2,4 & 10,02 & 0 & 11 & 2,5 & 50, \\
\hline I & 23 & 1 & 02 & $\begin{array}{l}2 \\
74\end{array}$ & 16 & $\begin{array}{c}52 \\
4\end{array}$ \\
\hline $\begin{array}{l}\text { Sumbe } \\
\text { r Daya }\end{array}$ & & & & & & \\
\hline Cukup & $\begin{array}{l}3,1 \\
13\end{array}$ & $\begin{array}{c}15,00 \\
2\end{array}$ & $\begin{array}{l}0 \\
00\end{array}$ & $\begin{array}{l}22 \\
, 4 \\
84\end{array}$ & $\begin{array}{l}4,6 \\
53\end{array}$ & $\begin{array}{l}10 \\
8,3 \\
61\end{array}$ \\
\hline $\begin{array}{c}\text { Disposi } \\
\text { si }\end{array}$ & & & & & & \\
\hline Baik & $\begin{array}{l}2,0 \\
96\end{array}$ & 8,191 & $\begin{array}{l}0 \\
04\end{array}$ & $\begin{array}{c}8, \\
13 \\
3\end{array}$ & $\begin{array}{l}1,9 \\
36\end{array}$ & $\begin{array}{c}34, \\
16 \\
5\end{array}$ \\
\hline $\begin{array}{c}\text { Struktu } \\
r\end{array}$ & & & & & & \\
\hline
\end{tabular}




\begin{tabular}{ccccccc}
$\begin{array}{c}\text { Birokra } \\
\text { si }\end{array}$ & & & & & & \\
\hline Baik & 3,2 & 16,74 &, 0 & 26 & 5,5 & 12 \\
& 88 & 6 & 00 &, 7 & 46 & 9,3 \\
& & & & 87 & & 65 \\
\hline
\end{tabular}

Pembahasan

Keberhasilan Implementasi Kebijakan

\section{Penanggulangan Bencana}

Evaluasi dari implementasi kebijakan yang dilakukan Pemerintah Kota Medan pada kejadian bencana banjir di Kota Medan dinilai oleh mayoritas masyarakat adalah cukup berhasil dengan nilai sebaran skor variabel keberhasilan implementasi penanggulangan bencana dinilai cukup baik yakni sebanyak 72 responden atau sebesar $67 \%$ dari keseluruhan responden dari keseluruhan responden. Hasil yang lebih tinggi diperoleh pada penelitian yang dilakukan oleh Christo Immanuel melaporkan sebanyak keberhasilan impelementasi penanggulangan bencana, khususnya di Kabupaten Minahasa Tenggara memiliki tingkat keberhasilan implementasi sebesar $71,3 \%$.

Faktor Yang Paling Mempengaruhi Tingkat Keberhasilan Implementasi Kebijakan

\section{Penanggulanganan Banjir}

Berdasarkan hasil analisis multivariat didapatkan dari keempat variabel yang diuji, variabel yang paling signifikan memengaruhi tingkat keberhasilan implementasi kebijakan penanggulangan banjir adalah struktur birokrasi, analisis multivariat menunjukkan responden dengan struktur birokrasi kategori baik 26,787 kali lebih menunjukkan keberhasilan implementasi yang baik. Struktur birokrasi mempunyai pengaruh yang cukup signifikan terhadap implementasi kebijakan.

Aspek struktur organisasi ini melingkupi dua hal yaitu mekanisme dan struktur birokrasi itu sendiri. Yang pertama adalah mekanisme, dalam implementasi kebijakan biasanya sudah di buat Standart Operation Procedure (SOP). SOP ini menjadi pedoman bagi setiap implementator dalam bertindak agar dalam pelaksanaan kebijakan tidak menyimpang dari tujuan dan sasaran kebijakan tersebut. Yang kedua adalah struktur birokrasi, apabila struktur birokrasi terlalu panjang dan terfragmentasi akan cenderung melemahkan pengawasan dan menyebabkan prosedur birokrasi yang rumit dan kompleks, yang selanjutnya akan menyebabkan aktivitas organisasi menjadi tidak fleksibel.

Struktur organisasi BPBD Kota Medan dibentuk sesuai dengan Peraturan Daerah No 15 tahun 2011 Tentang Organisasi dan Tata Kerja Badan Penanggulangan Bencana Daerah Kota Medan. Selain itu, juga berdasar kepada Peraturan Menteri Dalam Negeri No. 46 Tahun 2008 Tentang Pedoman Organisasi dan Tata Kerja Badan Penanggulangan Bencana Daerah. Di dalam struktur organisasi BPBD Kota Medan terdiri dari kepala badan yang membawahi unsur 
pelaksana dan unsur pengarah BPBD Kota Medan. Unsur pelaksana BPBD Kota Medan terdiri dari kepala pelaksana, sekretariat, seksi pencegahan dan kesiapsiagaan, seksi kedaruratan dan logistik serta seksi rehabilitasi dan rekonstruksi.

\section{Kesimpulan}

Berdasarkan hasil penelitian ini dapat disimpulkan bahwa:

1. Kategori tingkat keberhasilan implementasi kebijakan bencana banjir di Kota Medan dinilai cukup baik yakni sebanyak 72 responden atau sebesar $67 \%$ dari keseluruhan responden.

2. Kategori tingkat keberhasilan faktor komunikasi dalam keberhasilan implementasi kebijakan penanggulangan banjir bencana banjir di Kota Medan dinilai cukup berhasil yakni sebanyak 66 responden atau sebesar $62 \%$ dari keseluruhan responden.

3. Kategori tingkat keberhasilan faktor sumber daya dalam keberhasilan implementasi kebijakan penanggulangan banjir bencana banjir di Kota Medan dinilai cukup berhasil yakni sebanyak 66 responden atau sebesar $62 \%$ dari keseluruhan responden.

4. Kategori tingkat keberhasilan faktor disposisi dalam keberhasilan implementasi kebijakan penanggulangan banjir bencana banjir di Kota Medan dinilai cukup berhasil yakni sebanyak 63 responden atau sebesar $59 \%$ dari keseluruhan responden.

5. Kategori tingkat keberhasilan faktor struktur birokrasi dalam keberhasilan implementasi kebijakan penanggulangan banjir bencana banjir di Kota Medan dinilai cukup berhasil yakni sebanyak 63 responden atau sebesar 59\% dari keseluruhan responden.

6. Ada hubungan yang bermakna antara faktor komunikasi dengan keberhasilan implementasi kebijakan penanggulangan banjir $(p=0,016)$.

7. Ada hubungan yang bermakna antara faktor sumber daya dengan keberhasilan implementasi kebijakan penanggulangan banjir $(p=0,0001)$.

8. Ada hubungan yang bermakna antara faktor disposisi dengan keberhasilan implementasi kebijakan penanggulangan banjir $(p=0,001)$.

9. Ada hubungan yang bermakna antara faktor struktur birokrasi dengan keberhasilan implementasi kebijakan penanggulangan banjir $(p=0,0001)$.

10. Faktor yang paling dominan dan mempengaruhi keberhasilan implementasi kebijakan penanggulangan banjir di Kota Medan adalah struktur birokrasi. 


\section{Ucapan Terimakasih}

Ucapan terimakasih disampaikan kepada Ketua Yayasan Sari Mutiara Medan dan Rektor Universitas Sari Mutiara Indonesia, serta pihak-pihak yang telah membantu dalam penelitian ini

\section{Daftar Pustaka}

[1] S. Adinda. Evaluasi implementasi kebijakan dalam penanggulangan bencana banjir (studi kasus di kawasan perumahan pondok gede permai, jatiasih, kota bekasi periode 20132014). Jurusan IImu Pemerintahan. Fakultas IImu Sosial dan IImu Politik Universitas Diponegoro. 2014.

[2] L. Agustino. Dasar-dasar Kebijakan Publik. Alfabeta Bandung.2008.

[3] H. Andi. Analisis Penanggulangan Bencana Banjir di Kecamatan Ganra Kabupaten Soppeng. Jurusan IImu Pemerintahan. Fakultas IImu Sosial dan Ilmu Politik Universitas Hassanudin. 2017.

[4] Anik. Analisis tingkat kerentanan banjir dengan pendekatan geoekosistem di sub das babura provinsi sumatera utara. Universitas Sumatera Utara. 2011.

[5] Anonimous. Undang-undang No. 24 tahun 2007 Tentang Penanggulangan Bencana 2007.
[6] Baskornas

PB.

Pedoman

Penanggulangan Bencana Banjir. Jakarta: Republik Indonesia. 2017.

[7] B. Alamsyah. Penanganan problematik banjir kota medan berdasarkan pendekatan partisipasi masyarakat. Universitas Panca Budi. 2018.

[8] Badan Nasional Penanggulangan Bencana RI. Data Bencana Indonesia 2017. RI: Jakarta. 2017.

[9] C. Imanuel. Implementasi kebijakan penanggulangan bencana (suatu studi di badan penanggulangan bencana daerah kabupaten minahasa tenggara). 2017.

[10] Deputi Bidang Sarana dan Prasarana, Direktorat Pengairan dan Irigasi. Kebijakan Penanggulangan Banjir di Indonesia. Jakarta: Republik Indonesia. 2016.

[11] F. irfany. Implementasi kebijakan mitigasi Bencana banjir di kabupaten bandung studi kebijakan mitigasi bencana banjir di desa dayeuhkolot kabupaten bandung. Universitas Pasundan Bandung. 2019.

[12] G. Ramadhan. Implementasi kebijakan penanggulangan banjir di DKI Jakarta 2013-2017. Universitas Tirtayasa.

[13] S. Ridha. 2017. Pemetaan tingkat risiko banjir dan longsor sumatera utara berbasis sistem informasi geografis. Universitas Negeri Medan. 2018. 
Jurnal Bidang Ilmu Kesehatan

[14] Meidina. Analisis mitigasi banjir di

[15] Nobrya. Analisis permasalahan daerah aliran sungai babura berbasis pengelolaan sungai deli. Universitas sistem informasi geografis (sig), Sumatera Utara. 2016.

Universitas Sumatera Utara. 2017. 